\title{
perifèria
}

Número 10, Junio 2009

www.periferia.name

\section{Dones públiques, homes ocults.}

Francesc Reig, Aina Bernal i M. Bruna Alvarez - UAB.

\begin{abstract}
Paula Medeiros, Regina (2000. 3a ed. 2002). Hablan las putas. Sobre prácticas sexuales preservativas y SIDA en el mundo de la prostitución. Virus. Crónica.
\end{abstract}

Después de frecuentar durante más de un año el ambiente de la prostitución en el Barrio Chino de Barcelona -y sobre la base del testimonio directo de sus protagonistas-, Regina de Paula Medeiros ha trazado un vivo mapa urbano y humano de las redes sociales y problemáticas propias del mundo de la prostitución en cualquier gran urbe occidental.

La prostitució ha estat i segueix sent un tema tabú. Se'n parla per fer broma, quan volem insultar, com un problema social, però gairebé mai s'ha escoltat a les putes.

Aquest llibre pretén, precisament, donar veu a aquestes treballadores del sexe, que parlin de la seva feina, dels clients, de l'ambient. En definitiva, que obrin la porta a la seva manera de veure el món i d'enfocar la vida.

No deixa de ser significatiu que hagi de ser Regina de Paula Medeiros, una brasilera, la que vingui a Barcelona a fer una tesi doctoral ${ }^{1}$ sobre prostitució, de la qual en sortirà el llibre ressenyat. Ni tampoc que trobi força impediments acadèmics alhora de presentar i iniciar el tema, i que després, una vegada enfocada la investigació fora de l'àmbit universitari, trobi diversos "voluntaris" per a dirigir el seu treball etnogràfic. I és que la prostitució, tan a mitjans dels anys 90 , moment en què Regina Paula Medeiros va realitzar el seu treball de camp, com actualment, és un tema controvertit.

\footnotetext{
${ }^{1}$ La tesi doctoral va ser dirigida per Oriol Romaní, de la Universitat Rovira i Virgili. Es va presentar I'any 1996 i el llibre va sortir publicat l'any 2000.
} 


\section{perifèria}

Número 10, Junio 2009

www.periferia.name

L'autora ha estat fortament vinculada, tan acadèmica com professionalment, als estudis de salut i de la SIDA. Va iniciar la seva formació acadèmica a Brasil, on va obtenir el Gradução em Serviço Social ${ }^{2}$ per la Universidade Federal de Juiz de Fora, al 1976. Des del 1981 és tècnica superior de la Fundação Hospitalar do Estado de Minas Gerais ${ }^{3}$ a Brasil, on és coordinadora del Programa de Prevenção de AIDS del Centro Mineiro de Toxicomania ${ }^{4}$. El 1986, obté l'especialització en Salut Pública ${ }^{5}$ i al 1987 obté I'especialització en antropologia ${ }^{6}$, amb un treball final titulat: AIDS: um rito de passagem ${ }^{7}$. Entre el 1993 i el 1997 va realitzar la seva tesi doctoral Aquí te pillo, aquí te mato! La construcción social de las relaciones sexuales en el mundo de la prostitución del barrio Chino- Barcelona, a la Universitat Rovira i Virgili (Tarragona), el resultat de la qual, és el llibre que es ressenya a continuació.

El tema de la prostitució ha estat àmpliament tractat des de diversos vessants, per exemple, des d'un marc teòric de gènere i de la marginació (D. Juliano), des del tràfic i l'esclavitud sexual (B. Kathleen, M. LI. Maqueda, R. Osborne, A. Alonso), com una sortida per a les dones migrants (Sara Carmona), des d'un punt de vista històric (P. Dufor, García de Fagoga), com a autobiografies (G. Peherson, I. Pisano, V. Tasso), o bé com a protocols d'actuació redactats per les administracions públiques. Poques vegades, però, s'ha estudiat la prostitució a partir d'un treball etnogràfic, com si que fa Ignasi Pons sobre la prostitució a Astúries a La cara oculta de la luna (1992), treball pioner en aquest àmbit. Hablan las putas és, per tant, una aproximació rellevant a una realitat existent i propera a nosaltres i, de fet, serà un dels llibres més utilitzats en estudis posteriors sobre prostitució a Catalunya, com és el cas de la tesina d'Ariadna Alonso Menors migrades no acompanyades de I'Europa de l'Est. (2008: Inèdit).

\footnotetext{
${ }^{2}$ Graduat en Serveis Socials

${ }^{3}$ Fundació Hospitalària de I'Estat de Minas Gerais

${ }^{4}$ Programa de Prevenció del SIDA del Centro Mineiro de Toxicomania

${ }^{5}$ Especialització en Salut Pública per la Universidade Federal de Minas Gerais.

${ }^{6}$ Especialització en Antropologia a la Pontificia Universidade Catolica de Minas Gerais.

7 SIDA: un ritual de pas
} 


\section{perifèria}

Número 10, Junio 2009

www.periferia.name

Regina de Paula Medeiros ha estructurat I'obra de manera que facilita un apropament gradual i progressiu al món de la prostitució del "barri Xino" de Barcelona a mitjans dels anys 90. Aquesta obra està dividida en quatre parts: la introducció, el marc teòric, el treball etnogràfic i les conclusions.

A la introducció, l'autora presenta la seva obra, l'origen del seu treball, així com el tema de la relació entre SIDA i prostitució, que correspon a un dels blocs temàtics més importants del llibre. Aquest aspecte, per això, és un dels punts menys treballats en la part etnogràfica, tot i que posteriorment reprèn aquest tema i el seu marc teòric per exposar les seves conclusions. En aquesta part, l'autora també ens explica el contingut del llibre, així com els motius que I'han dut a realitzar aquesta investigació.

Un dels aspectes, però, menys treballats, són aquells que més tenen a veure amb qüestions de tipus metodològic. L'autora ens presenta la seva obra, però en canvi no explicita les hipòtesis, i, per tant no és possible la seva contrastació. D'altra banda, tampoc acaba de descriure els objectius d'una manera clara, ni la finalitat de la mateixa.

Els conceptes més interessants plantejats per l'autora en el marc teòric, són aquells que tenen a veure amb els aspectes culturals de la sexualitat, la seva construcció $i$ el seu simbolisme. Així, l'existència de conceptes culturals associats al món de la sexualitat permet classificar els comportaments sexuals com a normals -associats a la procreació- i els perversos i/o desviats -associats al plaer, i per tant, definint un comportament normatiu i un de transgressor.

És particularment interessant I'anàlisi que fa l'autora del concepte de desig com a resultat de la combinació dels símbols culturals. En aquest sentit, cobra gran importància el simbolisme dels imaginaris eròtics o les fantasies sexuals, associats a la ruptura de les normes morals sexuals, relacionant el concepte de perversió dins el marc del psicoanàlisi, introduint aspectes freudians en I'anàlisi de la fantasia i la transgressió de la normativa sexual i la implicació de tabús i prohibicions. 


\section{perifèria}

Número 10, Junio 2009

www.periferia.name

En l'àmbit de la sexualitat, l'autora estableix una tríade formada per la construcció del gènere (passiu-dona i actiu-home), el concepte de perversió (plaer i no procreació) i de normalitat (relació heterosexual); i que té molt a veure amb les tendències hegemòniques, i per tant, social i culturalment elaborades.

Per altra banda, I'autora fa un plantejament teòric de les relacions sexuals on es descriu la interrelació entre conceptes com fantasia, plaer, orgasme, etc, a la vegada que aprofundeix en l'estudi de la construcció social de les relacions sexuals en el món de la prostitució, des d'una perspectiva femenina i masculina, fet que permet establir diferències en les construccions culturals de la sexualitat en un i altre gènere, introduint també, elements que tenen a veure amb la construcció social de la homosexualitat i les seves derivacions en l'elaboració de l'imaginari de la mateixa, en la societat.

En definitiva, es fa un bon plantejament teòric del fenomen de la relació sexual en la prostitució, tan com a objecte d'una transacció econòmica, emmarcada en un univers simbòlic.

Ara bé, com a contrapartida, s'ha de destacar que aquesta part resulta una mica complexa de comprendre i analitzar, fet que pot redundar en una manca de comprensió de determinats elements i aspectes treballats en I'obra.

La tercera part, la més extensa de I'obra, correspon a l'etnografia. Aquesta està escrita amb un llenguatge planer i amè, i està complementada amb cites textuals de les informants, plenes d'ironia en molts casos.

A l'inici de l'etnografia s'exposen el conjunt de tècniques emprades en el treball etnogràfic: principalment l'observació participant de l'ambient i el context en el qual es practica la prostitució, i les entrevistes en profunditat a les informants, totes elles prostitutes -incloent els transvestits. Hi manca, per això, que l'autora especifiqui la utilització o no del diari de camp, ja que d'aquesta manera, es faria una descripció més clara de la metodologia utilitzada en la realització del treball etnogràfic. D'altra banda, és criticable que no descrigui la manera d'accedir als 


\section{perifèria}

Número 10, Junio 2009

\section{www.periferia.name}

dossiers del $\mathrm{SAPS}^{8}$, ja que, en principi, és informació mèdica confidencial. Pel que fa a altres tècniques utilitzades, hauria estat interessant complementar les entrevistes amb enquestes a un grup més ampli d'informants. Aquest és de fet, un dels punts més febles del treball etnogràfic, ja que aquesta aportació d'informació complementària hauria permès dur a terme un treball més de tipus comparatiu, possibilitant, per tant, el creuament d'informació entre els diferents tipus d'informants.

A nivell més descriptiu i d'anàlisi del treball etnogràfic, l'autora estableix una classificació, a partir de la informació aportada per les prostitutes, així com del treball d'observació participant, de manera que les classifica en tres grups: dones que assumeixen públicament el seu ofici, i que viuen al barri, dones que exerceixen la prostitució en secret ("Belle Jour"), i per últim, els transvestits. En aquest sentit, mancaria especificar a quin grup de prostitutes pertanyen les seves informants; aspecte que facilitaria l'anàlisi per part del lector que, d'aquesta manera, tindria més elements rellevants per a poder arribar a les seves pròpies conclusions. Pel que fa la grup de les "Belle Jour", I'autora comenta que en aquest grup en particular la principal motivació per exercir la prostitució no passa, com per exemple en el primer grup, per qüestions únicament econòmiques, fet que per altra banda no aprofundeix i seria un tema interessant d'abordar.

Un aspecte a considerar, i que pot generar una certa controvèrsia, té a veure amb el fet que l'autora és planteja el pagament simbòlic, com a una manera lícita d'accedir a les seves informants. De fet, en la introducció al treball etnogràfic, Regina Paula Medeiros considera que el pagament amb diners per a l'obtenció d'informació és un element que pot influir de forma negativa en la relació entre l'etnògrafa i les informants. Ara bé, l'alternativa del pagament simbòlic (menjar, tabac, etc), justificat per l'autora com a un tracte deferent vers les informants, dóna joc a la construcció d'un vincle basat en la reciprocitat i que de fet culminà amb un intercanvi de regals en ambdós sentits.

\footnotetext{
${ }^{8}$ SAPS (Servei d'Atenció i Prevenció Sociosanitaria per a la Drogadicció).
} 


\section{perifèria}

Número 10, Junio 2009

www.periferia.name

Un dels aspectes més importants i que donen major rellevància al treball etnogràfic, és el retorn del resultat de la investigació als subjectes d'estudi. Cal destacar el fet que I'autora, abans de presentar definitivament l'etnografia, la retorna a les informants, per tal que puguin confirmar les seves paraules i els seus punts de vista. D'aquesta manera el seu treball s'enriqueix amb aquesta aportació addicional al treball etnogràfic. En aquest sentit s'estableix un vincle de relació autèntica, necessària i d'implicació per part de l'antropòloga. Fet que redunda de forma positiva en l'autopercepció de les informants com a autèntiques protagonistes actives i decisives en el treball etnogràfic.

Un dels punts del treball etnogràfic que pot suscitar majors crítiques, és el que fa referència a la construcció de la relació sexual, partint del punt de vista de les seves informants, sense tenir en compte la visió de la mateixa, per part del client. Tal i com ho planteja l'autora, podria semblar que hi ha certes reticències, per part del client, a participar en el treball etnogràfic. Amb tot, aquest treball etnogràfic no respon a aquesta finalitat, sinó a la de donar el protagonisme a les prostitutes.

L'autora descriu la prostitució com a una pràctica comercial objectiva i real en I'àmbit del mercat de treball -amb una demanda i una oferta- però que en canvi no és reconeguda per la societat. En aquesta mateixa línia, l'autora proposa un anàlisi simbòlic de I'univers de la prostitució, on la simbologia ha de ser interpretada a través de les estructures de poder i de la capacitat de transformarles. La relació entre client i prostituta interpretada com una relació de poder, obtingut a través de formes i significats culturals d'allò eròtic i construït per mitjà dels conceptes de gènere i marcat per la desigualtat i la diferència.

La quarta i última part de la monografia són les conclusions. Aquestes tracten sobre el discurs dels experts sobre la SIDA i la seva relació amb la prostitució, que vincula la SIDA al sexe no normatiu, pervers, al sofriment del cos i finalment a la mort, conseqüència de la decadència física i marcada per l'estigma social. 


\section{perifèria}

Número 10, Junio 2009

www.periferia.name

Amb aquest discurs, per les prostitutes, considerades com a treballadores de la part perversa del sexe, la SIDA es transforma en un pes social, que han de suportar. Les prostitutes consideren, a més a més, que els grups marginals, entre els quals es troben, són encara tractats a mode de cap de turc.

També apareixen aquí les polítiques institucionals encarregades de tractar la SIDA. L'autora afirma que aquestes creen unes normes de conducta, basades en models ideològics, que han de ser adoptades per determinats grups, considerats d'alt risc entre els quals es troba el de les prostitutes. Aquestes polítiques presenten, a més a més, una solució única per evitar la transmissió de la SIDA que és I'ús del preservatiu, independentment de la cultura i de l'estructura de les pràctiques sexuals. En aquest context, l'administració converteix a la prostituta en la responsable de la prevenció de la SIDA a l'ambient, així, com la única responsable de la introducció del preservatiu en les seves relacions sexuals.

La SIDA, en particular, i les malalties de transmissió sexual en general, no són considerades, ni per les prostitutes ni pels clients, com d'alt risc. El preservatiu no és tampoc considerat com la poció màgica, sinó que les informants pensen que és més important la capacitat de negociació de les pràctiques sexuals i el coneixement de trucs varis per a la introducció del preservatiu a la relació sexual, a vegades sense que el client se n'adoni.

L'autora també presenta tots aquells elements simbòlics que fan possible la responsabilització de les prostitutes de la SIDA:

La vinculación del SIDA a la imagen social de la marginalidad, desviación y transgresión por parte de los discursos articulados por los expertos, así como las políticas formuladas para la prevención, permiten hacer responsable a la prostitución, entre otros grupos, de la transmisión del virus (p.224).

D'altra banda, els clients, tot i freqüentar els espais considerats com a marginals, no se'ls responsabilitza, ja que representen la "norma": són considerats, moltes vegades, com víctimes de la transmissió; i poques, com a difusors del virus entre la població heterosexual. 


\section{perifèria}

Número 10, Junio 2009

www.periferia.name

En definitiva, Regina Paula de Medeiros afirma que les polítiques institucionals són dictades sense un anàlisi de les relacions sòcio-culturals ni una contextualització històrica. Finalment, l'autora presenta l'antropòleg/a com un personatge clau en evitar l'expansió de l'epidèmia de la SIDA i en el coneixement de la construcció cultural de la sexualitat. L'autora fa una crítica a les polítiques institucionals i reivindica la figura de l'antropòloga per a entendre la diversitat sexual, social i cultural de la societat moderna.

Tenint en compte les dificultats per trobar monografies sobre la prostitució al nostre país podria semblar que el tema suscita poc $o$ nul interès a nivell acadèmic $i$ institucional. De fet, són pocs els treballs que han abordat aquest tema des d'una perspectiva etnogràfica, no tant a nivell teòric. Aquest fet per sí sol ja es indicatiu de com la societat en general aborda la qüestió de la prostitució, la seva problemàtica social i individual. Sovint el discurs dominant, construït des del poder, ha tendit a atribuir a la prostituta el paper de víctima, estigmatitzant-la i per tant excloent-la de les esferes de decisió. Darrera aquesta actitud paternalista s'amaga una visió de la prostitució que no respon a la realitat, i que és més fruit de creences irracionals basades en el desconeixement i negació de la seva situació. En general, es considera la puta com una víctima, i com a tal, no sap el que vol, o el que necessita. Es tracta a la prostituta des d'una perspectiva paternalista, com si ella fos un infant, a qui s'ha de "portar pel bon camí".

Així doncs, ens hem trobat davant un llibre que aborda la temàtica de la prostitució des d'un vessant innovador, que trenca amb els estereotips del món acadèmic, i que és capaç de donar eines a l'administració pública, per tal que s'estableixi un diàleg amb les prostitutes, en quan a millorar el seu àmbit laboral, i evitar, d'aquesta manera, l'explotació sexual. Per tant, es tracta d'un apropament al tema des de l'antropologia aplicada, ja que l'autora dóna veu a les protagonistes d'algunes polítiques socials, a les quals no se'ls demana mai opinió.

En un altre ordre d'idees, aquesta obra assenyala el punt de partida a partir del qual és possible analitzar la prostitució des d'una perspectiva de gènere, perquè no només s'obté informació sobre les relacions de les prostitutes i els clients, sinó també, d'aquells aspectes que, per ser tabú, la societat intenta amagar, però que 


\section{perifèria}

Número 10, Junio 2009

www.periferia.name

es visualitzen en el món de la prostitució. En aquest sentit, uns dels objectius de l'obra és el d'aportar informació sobre la cara fosca, que la societat intenta ocultar. En aquest context, es pot obtenir molta informació sobre la canalització de les desigualtats de gènere, ja que les prostitutes són coneixedores de realitats, com per exemple de comportaments i imaginaris masculins que no es corresponen amb els estereotips de masculinitat que cal representar, i que en els altres àmbits socials, com per exemple la família, es tendeixen a amagar.

Però alhora, la prostituta, quan no treballa, és una dona, que s'integra a la societat complint amb els rols femenins, en base als comportaments esperats en funció de gènere i que són fruit de la pressió cultural que la societat exerceix sobre ella espera d'ella. Tal i com menciona l'autora:

La prostituta (femenina), en este contexto, ocupa un espacio ambivalente, pues, por una parte, representa un comportamiento transgresor, ocupando el lugar público de la calle, lo que la sitúa en el lugar de lo activo; mientras que, por otra parte, está situada en el lugar de lo pasivo, para servir al hombre-norma (satisfaciendo sus deseos sexuales) y a la sociedad (minimizando conflictos sociales y económicos). Por lo tanto, es rechazada y aceptada al mismo tiempo (p.16).

La prostituta és un mal necessari, per canalitzar els conflictes socials que comporta la relació desigual entre els gèneres.

Implícitament, amb aquesta obra, l'autora pretén trencar amb alguns estereotips associats al món de la prostitució, com ara la relació entre prostitució i SIDA o prostitució i drogoaddicció. De fet aquests tipus de relacions s'estableixen en base a construccions socials que responen a arquetipus concrets dins l'imaginari col-lectiu, com a estigmes associats al món de la marginació i exclusió social.

El treball etnogràfic, també s'emmarca dins el context d'aparició del VIH i com aquesta malaltia, en els seus orígens, s'associava al món de la marginació, prostitució i homosexualitat. Ara bé, la ràpida expansió del virus a diferents nivells socials, allunyant-se per tant dels nuclis inicials de marginalitat, suposà un replantejament, per part de les administracions, de les mesures a prendre per a frenar la propagació de la malaltia. En aquest sentit, l'autora fa una crítica explícita a les polítiques dutes a terme per part de l'administració pública per frenar l'avanç 


\section{perifèria}

Número 10, Junio 2009

www.periferia.name

de la SIDA, entre les quals hi ha l'atribució de la responsabilitat en I'ús del preservatiu única i exclusivament en la prostituta, obviant per tant, la responsabilitat en el seu ús per part del client.

L'autora trenca també, la relació estigmatitzada entre droga i prostitució, ja que tot i descriure que hi ha prostitutes drogoaddictes que treballen per poder comprar la droga, el seu treball etnogràfic es basa únicament, en prostitutes que no formen part del grup de drogoaddictes, i que treballaven al barri des de molt abans que aquelles.

Finalment, la lectura d'aquesta monografia conduirà al lector, d'una forma subtil, elegant i atrevida en el fascinant món, sovint ocult i amagat, de la prostitució al barri Xino, un lloc de trobada de les més exòtiques i heterogènies formes de vida concentrades en poc més d'un quilòmetre quadrat, on s'amalgamen la cara visible i la cara oculta de la mateixa societat.

\section{Bibliografía}

Alonso, A. (2008). Menors migrades no acompanyades de l'Europa de l'Est. Inèdit. Barry, K. (1998). Esclavitud sexual de la mujer. Barcelona: Lasal: edicions de les dones.

Carmona Benito, S. (2000). "Inmigración y prostitución: El caso del Raval (Barcelona)". Papers, 60. Universitat Autònoma de Barcelona, pp. 343-354.

Checa Olmos, F. et al. (2006). Menores Tras La Frontera: Otra Inmigración Que Aguarda. Barcelona: Icaria.

Dufour, P. (1999). La prostitución en la Antiguedad: en las primeras civilizaciones, en Babilonia, en Fenicia, en el Antiguo Egipto, en el Antiguo Testamento y el la Grecia Clásica. Editorial: ROGER. Traductor: CECILIO NAVARRO. San Sebastián.

García de Fagoga, J. (2002). Putas de España: de la ilustración a la democracia. Madrid: Irreverentes.

Juliano, D. (2001). Las prostitutas: El polo estigmatizado del modelo de mujer. Madrid: Talasa.

Juliano, D. (2002). La prostitución : el espejo oscuro. Barcelona: Icaria - Institut Català d'Antropologia. 


\section{perifèria}

Número 10, Junio 2009

www.periferia.name

Juliano, D. (2004). Excluidas y Marginales: Una Aproximación Antropológica. Madrid: Cátedra.

Kottak, C. P. (2002). Antropología Cultural. 9a ed. Madrid: McGraw-Hill.

Maqueda Abreu, M. L. (2001). El Tráfico Sexual De Personas. València: Tirant lo Blanch.

Osborne, R. (2004). Trabajador@s Del Sexo: Derechos, Migraciones y Tráfico En El Siglo XXI. Barcelona: Bellaterra.

Pheterson, G. (1992). Nosotras, las putas. Madrid: Talasa.

Pheterson, G. (2000). El prisma de la prostitución. Madrid: Talasa.

Pisano, I. (2001). Yo puta: hablan las prostitutas. Barcelona: Plaza y Janés.

Pons, I. (1992). La cara oculta de la luna. Condiciones de vida de las prostitutas en Astúrias. Publicacions UAB.

Tasso, V. (2004). Diario de una ninfómana. Barcelona: Plaza y Janés. 